\title{
Human Resources or Information Technology: What is More Important for Companies in the Digital Era?
}

\author{
Lejla Turulja, Nijaz Bajgorić \\ School of Economics and Business, University of Sarajevo, Bosnia and \\ Herzegovina
}

\section{Abstract}

Background: Companies can improve their business performance, increase revenues and reduce costs by enhancing their information technology (IT) capability. On the other side, there is an increasing importance of human resource management (HRM) practices related to IT utilization, which are important for the business performance of a company in the rapidly changing knowledge-based economy. Objectives: The objective of this paper is to analyze the relations among IT capability, HRM capability and the firm's performance outcomes. Methods/Approach: The paper uses survey data and Structural Equation Modeling to analyze the relationships among IT capability, HRM capability and firms' performance. Results: This paper reveals that IT capability to some extent determines firms' business performance but it plays more important role in enhancing HRM capability. In addition, HRM capability significantly impacts business performance. Conclusions: The findings indicate that managers should not focus on allocating resources only for IT investments. In order to achieve better business performances, these technologies need to be used to support all business processes including HRM activities.

Keywords: information technology capability; human resource management capability; business performance; dynamic capability view

JEL classification: M15, M12

Paper type: Research article

Received: October 01, 2015

Accepted: Mar 07, 2016

Citation: Turulja, L., Bajgorić, N. (2016), "Human Resources or Information Technology: What is More Important for Companies in the Digital Era?", Business Systems Research, Vol. 7, No. 1, pp. 35-45.

DOI: 10.1515/bsrj-2016-0003

\section{Introduction}

Modern business is dependent on information technology (IT) and most companies are obliged to turn to electronic market in order to achieve competitive advantage 
and superior business performance. Companies implement information technologies in order to improve both efficiency and effectiveness of business processes. The importance of human resources (Song et al., 2005) and information technology (Chae et al., 2014) have been recognized in previous studies in the context of achieving superior business performances. However, a question arises: is it possible to give priority to one resource over another? Does information technology in the context of the digital era have a higher importance than human resources? This topic is especially important for firms whose main activity is not directly related to IT bearing in mind specific conditions of business in the "New Economy" and a particular need for business transformation from traditional to electronic business.

Business globalization and competition create business pressures on firms and managers to react faster and make better business decisions. Investments in the information technology are often considered business-critical factors for improving the quality of products and services, both efficiency and effectiveness of decision making and business processes. By leveraging their IT capability, modern businesses try to increase revenues, reduce costs, or both. On the other side, there is an increasing importance of HR practices for the firms' competitive advantage and business performance in the Digital economy, whose main characteristic is a turbulent business environment with rapid changes (Chen \& Huang, 2009). Consequently, when it comes to the digital age, there is a logical question of whether human resources or information technologies are more important for firms?

The knowledge-based economy in the 1990s came to be called the Digital economy or the New economy. This economy is based on dynamic, rather than static resources (Carlsson, 2004). Static resources are those resources that represent collection of assets to be used in an appropriate manner in the business activities (Barney, 1986). Dynamic capabilities help firms to deal with rapidly changing environments, considering the firm's abilities to create additional value (Teece et al., 1997) through constant improvement of the existing resources. In this connection, dynamic capability view (DCV) represents theoretical base of this paper. The central question addressed by DCV is how firms can obtain superior business performance which has long been examined by strategic management literature. DCV emphasizes firms' ability in modifying, integrating and reconfiguring organizational resource base to match changing environments (Teece et al., 1997).

In order to address the question of whether information technology has a higher importance than human resources in the digital era, we identified a research topic which would simultaneously analyze not only the relation between IT capability and HRM capability but the relations between these two constructs and performance as well. Most of the previous studies emphasized one specific causal link, without providing an integrative approach (Crawford et al., 2011; Chae et al., 2014). To fill this gap, we developed a research model that addresses relationships between IT capability, human recourse management capability and firm's performance. Thus, the objective of this research is to analyze the causal relations between these constructs considering the following research questions at the firm level:

- RQ1: How does IT capability affect human resource management capability?

- RQ2: How does human resource management capability improve firms' performance?

- RQ3: Does human resource management capability mediate the link between IT capability and firms' performance? 


\section{Literature Review}

\section{Human Resource Management Capability}

Human resources with their knowledge and experience are considered by many authors (Lin \& Hsu, 2010) the most valuable resources of the firm. Therefore, human resource management capability (HRMC) is a very important firm's capability. Skills and knowledge of human resources can be very difficult for competitors to imitate, which is one of the assumptions of so-called "VRIN" framework (valuable, rare, inimitable and non-substitutable) for resources to have ability to support achievement of sustainable competitive advantage (Barney, 1991).

Consistent with DCV, HRM capabilities can be defined as the ability of the firm to implement and maintain appropriate HRM practices in the areas of performance management, training and development, and compensation and rewards (Mäkelä et al., 2013; Perez-Lopez et al., 2005). In our research, we will use the conceptualization of HRM capability suggested by Pérez-López et al. (2005), where HRM capability is seen as a construct or a concept made up of four dimensions:

- Staffing and hiring is related to the selection criteria during recruitment of employees. Firms' focus should be on the capabilities that individuals show and which are related to creation and knowledge share, as well as their values and cultural fit. Pérez-López et al. (2005) emphasized a fact that firms should focus on social background and character references instead of searching for applicants with necessary skills for the job.

- Training refers to the education of employees during which they will acquire skills, concepts, or attitudes that should result in improved job performance.

- Employees' participation refers to greater participation of the employees in the processes of decision-making.

- The reward practices refer to the organizational compensation system and activities in which employees are rewarded and valued.

\section{Information Technology Capability}

Considering the growing importance of information in today's business environment, it is very important for firms to achieve capability with regard to several tools and processes used to manage information. In other words, following the investments in the particular information technology, firms should adapt business processes and routines for regular use of those technologies. In the end, firms should continuously improve knowledge and skills in technology usage. This capability is known as IT capability and there are three elements that can be identified: IT infrastructure, IT operations and IT knowledge. Most of the papers, while analyzing IT capabilities, focused on these three elements (Chakravarty et al., 2013). Based on it, firms' IT capability can be defined as the ability of firm to select, accept, configure and implement information technology.

In this paper, we will use conceptualization of IT capability defined by Pérez-López and Alegre (2012). In their study, IT capability is seen as a construct consisted of three dimensions:

- IT knowledge is a degree of awareness of IT benefits and possibilities within company as well as employees' IT knowledge and skills.

- IT operations relate to the level of use of IT in the firm's business activities, or transformation of activities in order to increase usage of IT.

- IT infrastructure includes hardware, software and support staff, or tools and resources that contribute to the acquisition, processing, storage, dissemination and use of information (Pérez-López \& Alegre, 2012). 
Taken together, these three dimensions of IT capability interact and impact the degree to which an organization can leverage its investments in IT for strategic gains (Crawford et al., 2011). Summing up, in order to develop IT capability, firms should invest in information technology, promote its use in business activities, and train employees aiming to improve their IT skills and increase awareness of IT benefits.

\section{Theoretical Model and Hypotheses}

In line with DCV of the firm, this paper offers a conceptual structural model and empirically tests the relationship between HRM capability, IT capability and business performance. The purpose of this study is to answer the question about the importance of IT and human resources for the company's business performance in the New economy. Both HRM and IT capabilities are two companies' dynamic capabilities recognized with this paper to be the most important factors for successful business in the digital era.

\section{Human Resource Management Capability and Business Performance}

Many scholars suggested HRM capability to be the most important enabler of superior business performance (Chang \& Huang, 2010; Song et al., 2005). At the other side, DCV presumes that firm's dynamic capabilities determine business success. Consequently, a special focus of researches is placed on the relationship between HR capability and business performance. According to many scholars, HRM capability is an important predictor of firm's competitive advantage (LengnickHall and Lengnick-Hall, 2012) and serves as a significant determinant of firm's business performance (Khandekar \& Sharma, 2005). Relationship between HRM capability and business performance lies on a simple assumption that better use and deployment of human resources by company will result in outstanding business performance. In line with this assumption and other studies that have revealed the positive impact of the HRM capability on firms' performance, we propose the following hypothesis:

H1: HRM capability has a positive impact on firm's business performance.

\section{Information Technology Capability and Business Performance}

Despite the widely held belief that information technology is important to a firm's growth and success, scholars are still struggling to provide the underlying theoretical explanation and empirical evidence of this link (Bharadwaj, 2000). The DCV indicates that firms can differentiate themselves from their competitors through development of IT capability. Therefore, it is very important for firms to properly understand the IT capability which is a broader concept than just investments in information technology.

Many scholars have shown that IT capability impacts business performance indirectly through other firm's resources and capabilities (Chakravarty et al., 2013). However, there are some authors like Bhardwaj (2000) who showed that companies with high IT capability tend to achieve better business performance. On the basis of these premises, second hypothesis of this research is:

H2: IT capability has a positive impact on firm's business performance. 


\section{Human Resource Management Capability and Information Technology Capability}

According to some scholars, information technology changes the role of the HR function (Steijn \& Van Den Muyzenberg, 2012). Even if it is possible to analyze IT capability of firms individually, IT has become integral part of all business processes so it is often seen as an integral part of all other firm's capabilities. IT can be used to develop competitive products or services as well as to improve decision-making processes. Consequently, it is expected from IT to improve, fasten and improve HR related administrative, operational and planning decisions (Broderick \& Boudreau, 1991). Thus, it is expected for IT capability to influence HRM capability positively, and the third hypothesis is:

H3: IT capability has a positive impact on HRM capability.

\section{Methodology}

\section{Sample}

We opted to use empirical analysis based on primary data collected through a survey conducted among firms in a SEE transition economy. The questionnaire consisted of measurement indicators for IT capability, HRM capability and business performance as well as firms' demographics. Limesurvey software is used for data collection. In total, 2966 calls for participation in the survey have been sent to the firms' management. The calls indicated the purpose of the study and highlighted anonymity for respondents in order to avoid common method bias. A total of 531 valid questionnaires were obtained. Of these 531 questionnaires, 87 had a high percentage of missing values, so we decided to eliminate them, following the complete case approach described in Hair et al. (2010). 444 questionnaires that had less than $20 \%$ of the missing data are left in the sample, and after finding that the missing data are MAR (missing at random), missing data are imputed with EM estimation technique. Companies were selected randomly from a database of all active firms. Sample structure in terms of companies' size is: $11 \%$ of micro, $37 \%$ of small, $38 \%$ of medium and $15 \%$ of large companies, with all of 19 industries offered in the questionnaire which are adopted from NACE classification.

\section{Measures}

Twenty-eight indicators were developed based on the systematic literature review. These indicators presented four dimensions of human resource capability, three dimensions of IT capability and business performance using seven-point Likert scale ranging from 1 - strongly disagree to 7 - strongly agree. Items are adopted from those authors who used wording that was easier to translate, taking into account the definition of the construct that should be presented by the indicator.

HRM capability (HRMC). The measurement model for HRMC was created using indicators proposed by Pérez-López et al. (2005) and Chen \& Huang (2009). HRMC reflective measurement model consisted of 14 items and 4 first-level factors.

IT capability (ITC). The measurement model for IT capability was created using indicators proposed by Tippins and Sohi (2003) and Kmieciak et al. (2012). IT capability is presented as second-order reflective model consisted of 3 first-order factors and 10 items in total.

Firms' business performance (FP). This first-order reflective measurement model is adopted from Chen \& Huang (2009) and it consisted of 4 items measuring firm's business performance in terms of profit, sales, return on investment and market share. 
Table 1

Research instrument description

\begin{tabular}{|c|c|c|}
\hline Construct & Code & Item \\
\hline \multicolumn{3}{|r|}{ Human Resource Management Capability } \\
\hline Selective hiring & $\begin{array}{l}\mathrm{SH} 4 \\
\mathrm{SH} 5\end{array}$ & $\begin{array}{l}\text { Permanent staff hiring is more common in the company. } \\
\text { Internal promotion takes priority over external hiring of staff to } \\
\text { occupy vacancies. } \\
\text { The members of the department or team, which the new } \\
\text { worker will be part, participate in the selection of candidates. } \\
\text { In the selective process, knowledge and experience are taken } \\
\text { into account. } \\
\text { In the selective process, the capacity to work in synergy and } \\
\text { continuous learning are taken into account. }\end{array}$ \\
\hline Strategic training & $\begin{array}{l}\text { ST1 } \\
\text { ST2 } \\
\text { ST3 } \\
\text { DM1 }\end{array}$ & $\begin{array}{l}\text { There are comprehensive policies and procedures for training } \\
\text { and development of employees in the firm. } \\
\text { Training programs are mainly based on firm-specific } \\
\text { knowledge. } \\
\text { Employees receive training during their professional life. }\end{array}$ \\
\hline $\begin{array}{l}\text { Participation of } \\
\text { the employees in } \\
\text { decision making }\end{array}$ & $\begin{array}{l}\text { DM2 } \\
\text { DM3 } \\
\text { CO1 }\end{array}$ & $\begin{array}{l}\text { Employees' participation in the decision-making process. } \\
\text { Inform to the employees about economic and strategic } \\
\text { information. } \\
\text { High level of personnel empowerment in the firm. }\end{array}$ \\
\hline Compensation & $\mathrm{CO} 3$ & $\begin{array}{l}\text { The organization has a mixed system of rewarding: fix + } \\
\text { variable. } \\
\text { The company offers incentives to its employees related to their } \\
\text { performance. } \\
\text { The company offers incentives to its employees related to their } \\
\text { effort and commitment. }\end{array}$ \\
\hline \multicolumn{3}{|r|}{ Information Technology Capability } \\
\hline IT knowledge & $\begin{array}{l}\text { ITK1 } \\
\text { ITK2 } \\
\text { ITK3 }\end{array}$ & $\begin{array}{l}\text { In our company, } \\
\text { we possess a high degree of IT-based technical expertise. } \\
\text { we possess a high degree of IT-based technical expertise. } \\
\text { we are very knowledgeable about new IT-based innovations. }\end{array}$ \\
\hline IT operations & $\begin{array}{l}\text { ITO1 } \\
\text { ITO2 } \\
\text { ITO3 } \\
\text { ITO4 }\end{array}$ & $\begin{array}{l}\text { we use IT to collect and analyze market information. } \\
\text { we frequently utilize decision-support systems. } \\
\text { there is clarity of vision regarding how IT contributes to business } \\
\text { value. } \\
\text { there is integration of business strategic planning and IT } \\
\text { planning }\end{array}$ \\
\hline IT infrastructure & $\begin{array}{l}\mathrm{ITI} 1 \\
\mathrm{ITI} 2\end{array}$ & $\begin{array}{l}\text { Our firm employs a manager whose main duties include the } \\
\text { management of our information technology. } \\
\text { Every year we budget a significant amount of funds for new } \\
\text { information technology hardware and software. } \\
\text { Our firm creates customized software applications when the } \\
\text { need arises. }\end{array}$ \\
\hline & FP1 & $\begin{array}{l}\text { Firms' Business Performance } \\
\text { Rating realized profits compared to its main competitors in the }\end{array}$ \\
\hline & FP: & $\begin{array}{l}\text { Rating realized sales compared to its main competitors in the } \\
\text { past } 3 \text { years. }\end{array}$ \\
\hline & FP3 & $\begin{array}{l}\text { Rating realized return on investment compared to its main } \\
\text { competitors in the past } 3 \text { years. }\end{array}$ \\
\hline & & $\begin{array}{l}\text { Rating realization of the planed market share in the past } 3 \\
\text { years. }\end{array}$ \\
\hline
\end{tabular}


In order to assess whether common method bias (CMB) is a problem in this study, we used Harman single factor test which is one of the most commonly used techniques that addresses this issue (Podsakoff et al, 2003). The results indicate that $C M B$ is not a serious problem in this research, i.e. $C M B$ is not of great importance, and therefore is unlikely to affect the results of the analysis. Furthermore, the psychometric properties of the measurement models were assessed using confirmatory factor analysis. Following nomological validity which was provided during the phase of questionnaire development, content validity was established through personal interviews with panel of experts: two scholars and four managers.

\section{Results}

Confirmatory factor analysis is used for analysis of reliability and validity of measurement models following recommendation of Hair et al. (2010). The analysis is conducted using Lisrel 8.8. Reliability is confirmed using Cronbach alpha coefficients and Composite Reliability (CR) measures. Convergent validity is assessed analyzing standardized factor loadings that should be greater than 0.5 and Average Variance Extracted (AVE) measures. Discriminant validity is confirmed by comparing square roots of AVE measures with constructs correlations. CR is the measurement of overall internal consistency of items in the factor structure (Hair et al., p. 689). Average variance extracted measures the extent to which the average variance of the indicators is explained by its theoretic construct (Fornell and Larcker, 1981).

Results show that all alpha coefficients are above threshold of 0.7. Furthermore, all variables of measurement models achieved an acceptable level of $C R$ with all values above threshold of 0.70 and acceptable levels of AVE with all values above threshold of 0.5 . Also, the correlation coefficients for all latent constructs are less than respective square root of AVE values. These results are reported in Tables 2, 3 and 4, showing that reliability as well as convergent and discriminant validity are achieved.

Table 2

Results of reliability and validity tests for measurement model of HRMC

\begin{tabular}{llccccccc}
\multicolumn{1}{c}{ Dimensions } & CR & AVE & RS & TR & PA & RE & a \\
\hline \multirow{2}{*}{ HRMC } & Recruitment and selection (RS) & 0.847 & 0.650 & $\mathbf{0 . 8 0 6}$ & & & & 0.836 \\
& Training (TR) & 0.856 & 0.666 & 0.690 & $\mathbf{0 . 8 1 6}$ & & & 0.851 \\
& Participation (PA) & 0.801 & 0.577 & 0.624 & 0.699 & $\mathbf{0 . 7 5 9}$ & & 0.807 \\
Reward (RE) & 0.831 & 0.623 & 0.417 & 0.389 & 0.461 & $\mathbf{0 . 7 8 9}$ & 0.825 \\
\hline
\end{tabular}

Source: Authors

Table 3

Results of reliability and validity tests for measurement model of ITC

\begin{tabular}{rlcccccc}
\hline \multicolumn{2}{r}{ Dimensions } & CR & AVE & ITK & ITO & ITI & a \\
\hline \multirow{3}{*}{ ITC } & IT Knowledge (ITK) & 0.867 & 0.685 & $\mathbf{0 . 8 2 8}$ & & & 0.860 \\
& IT Operations (ITO) & 0.869 & 0.624 & 0.788 & $\mathbf{0 . 7 9 0}$ & & 0.867 \\
& IT Infrastructure (ITI) & 0.794 & 0.566 & 0.714 & 0.778 & $\mathbf{0 . 7 5 2}$ & $\mathbf{0 . 7 7 5}$ \\
\hline
\end{tabular}

Source: Authors

Table 4

Results of reliability and validity tests for measurement model of FP

\begin{tabular}{llccc} 
& Dimensions & CR & AVE & A \\
\hline FP & Firm's performance (FP) & 0.889 & 0.671 & 0.885 \\
\hline
\end{tabular}

Source: Authors 
Table 5

CFA results for measurement models

\begin{tabular}{|c|c|c|c|c|c|c|}
\hline Measures & Items & $X^{2} / d f$ & RMSEA & SRMR & CFI & $\mathrm{NFI}$ \\
\hline HRMC & 14 & 2.76 & 0.0611 & 0.0385 & 0.983 & 0.974 \\
\hline ITC & 10 & 2.63 & 0.0590 & 0.0299 & 0.990 & 0.985 \\
\hline FP & 4 & 2.49 & 0.0580 & 0.0115 & 0.997 & 0.992 \\
\hline
\end{tabular}

Source: Authors

Measurement models overall fit are assessed by checking goodness-of-fit (GOF) indices. Results are presented in the Table 5. All of the indices values are above/below threshold value: RMSEA is less than 0.08, while SRMR is less than 0.05, $\mathrm{CFI}$ is greater than 0.9 and $\mathrm{NFI}$ is greater than the 0.95 cut-off value (Hair et al., 2010).

After confirming that reliability and validity of measurement models is achieved, structural model proposed in this study is analyzed by using Structural Equation Modeling (SEM) technique and maximum likelihood ( $M L)$ as the estimation method. Results are reported in the Table 6.

Table 6.

Hypothesis testing and GOF indices for conceptual structural model

\begin{tabular}{lccccc}
\multicolumn{1}{c}{ Hypotheses } & $\begin{array}{c}\text { Unstandardized } \\
\text { estimates }\end{array}$ & $\begin{array}{c}\text { Standardized } \\
\text { estimates }\end{array}$ & $\mathbf{t - \text { value }}$ & $\mathbf{R}^{2}$ & Result \\
\hline H1: HRMC $\rightarrow$ FP & 0.453 & $0.241^{* * *}$ & 2.957 & 0.116 & Accepted \\
\hline H2: ITC $\rightarrow$ FP & 0.205 & $0.128^{*}$ & 1.630 & 0.116 & Accepted \\
\hline H3: ITC $\rightarrow$ HRMC & 0.579 & $0.676^{* * *}$ & 9.040 & 0.457 & Accepted \\
\hline Chi-Square=562.375; df=289; RMSEA=0.0462; SRMR=0.0502; NFI=0.967; NNFI=0.981; CFI=0.983 \\
\hline$* * * \mathrm{p}<0.01 ;{ }^{* *} \mathrm{p}<0.05 ;{ }^{*} \mathrm{p}<0.1$
\end{tabular}

Structural model is analyzed through two steps. First, model overall fit is checked using GOF indices. Second, hypothesis are tested and results are analyzed and discussed in the light of the theoretical foundation. As the table 6 reports, the overall model demonstrates an acceptable fit. All indices are at acceptable levels and above/below threshold values (RMSEA<0.08; SRMR<0.08; CFI>0.9; NFI/NNFI>0.95). $\mathrm{x} 2 / \mathrm{df}$ is 1.95 which is below acceptable cut-off value of 3.00 or 5.00 (Hair et al., 2010).

Hypothesis testing revealed acceptance of all of the three hypothesis. First, the results indicate positive and significant relation between HRMC and FP, as it is suggested with $\mathrm{H1}: \beta=0.241, t=2.957, \mathrm{p}<0.01$. In other words, HRM capability positively influence company's business performance. Furthermore, the results of the analysis support the hypothesis about causal positive relation between ITC and HRMC: $\beta=0.676, t=9.040, p<0.01$. Regarding hypothesis 2 , the results show that there is positive relationship between ITC and FP at the significance level of $p<0.1: \beta=0.205$, $t=1.630$. Our findings provide empirical support for the proposed structural model about causal relations between HRMC, ITC and FP, which is based on the theoretical foundation of dynamic capability view.

\section{Discussion}

Many scholars emphasized an important role of human resource management suggesting that HRM capability can help achieve superior business performance. Another group of authors considered information technology as the most important resource for companies in the digital era, mostly because of the appearance of different business models as a result of rapid development of IT. 
However, there has been limited empirical research on the role of IT capability and its relation with HRM capability. We focused our research on the causal relations between IT capability, HRM capability and firms' business performance offering a conceptual model and its empirical analysis. The key findings from this study contribute to the both IT business value literature and management literature. Results explain how IT capability contributes to firms' business performance directly and indirectly through HRM capability. Specifically, the results of the study indicate that IT capability enhances HRM capability, which improve firms' business performance. Our integrated perspective on IT and human resources taken together helps us to analyze the role of IT capability in generating business performance together with HRM capability. This is aligned with the premise that information technologies are closely embedded in all business processes and routines within contemporary firms (Chen et al., 2015). IT capability is so intricately embedded in organizations that most capabilities necessarily are facilitated by it.

This research was conducted to analyze the importance of information technology and human resources for firms in the context of the digital era. We tried to find out if it is possible to give priority to one resource over another. Is information technology, due to its role in the new business models of the digital era more important than human resources? Our results suggest that HRM capability has more significant direct impact on business performance than IT capability. These results confirm that human resources with their knowledge and experience are the most valuable resources of the company. However, even though the impact of IT capability on business performance is almost insignificant, results show that there is a high positive impact of IT capability on HRM capability. In other words, ITC enhances HRMC, and indirectly supports business performance. So, if we consider just relations between ITC and FP, and HRMC and FP, we can conclude that human resources are more valuable for firms. However, our integrated model on IT and human resources together shows the importance of both capabilities in generating business performance. In other words, correct answer to our starting dilemma about importance of human resources and information technologies for the firms in the digital era would be that both capabilities have almost same importance for the companies. Considering the incorporation of IT in all business processes within contemporary firms, it is important to highlight that most of the firms' capabilities are necessarily facilitated by information technology, including HRM capability.

\section{Conclusion}

The paper offers and empirically analyzes a structural model that establishes an integrative view on the relations between IT capability, HRM capability and companies' business performance. Our findings provide empirical support for the relation between IT capability and HRM capability in a way that IT capability facilitates HRM capability. This result is consistent with results of some previous researches (e.g. Broderick \& Boudreau, 1991). In addition, this research empirically proves that HRM capability influences firms' performance positively. It demonstrates the mediating role of HRM capabilities in creating and capturing value from information technology. The results confirm that IT capability, on its own, is insufficient to generate superior business performance. But, IT capability together with human resource practices will results with firms' success.

The paper contributes to the DCV showing how the interaction of various resources impact firms' performance. Conclusively, this article has sought to advance the existing knowledge of ITC and HRMC as important capabilities in the global business environment, supporting premises of DCV. 
The main limitation of this study may be related to the subjective measures used for all indicators. Objective measures would increase the reliability of the results. Furthermore, our findings were drawn from a setting of transitional economy, and should be tested in developed countries as well. Future research should incorporate employees' related capabilities in exploring the effects of capabilities on firms' success.

\section{References}

1. Barney, J.B. \& Clark, D.N. (2007), Resource-Based Theory: Creating and Sustaining Competitive Advantage.

2. Barney, J.B. (1991), Firm Resources and Sustained Competitive Advantage, Journal of Management, Vol. 17 No. 1, pp. 99-121.

3. Barney, J. B. (1986). Strategic Factor Markets: Expectations, Luck, and Business Strategy. Management Science, 32(10), 1231-1241.

4. Bharadwaj, A. (2000), A resource-based perspective on information technology capability and firm performance: an empirical investigation, MIS Quarterly, Vol. 24 No. 1, pp. 169-196.

5. Broderick, R. F., \& Boudreau, J. W. (1991), Human Resource Management, Information Technology, and the Competitive Edge, Ithaca, NY: Cornell University, School of Industrial and Labor Relations, Center for Advanced Human Resource Studies.

6. Carlsson, B. (2004), The digital economy: what is new and what is not? , Structural Change and Economic Dynamics, 15: pp. 245-64.

7. Chae, H., Koh, C., \& Prybutok, V. (2014), Information technology capability and firm performance: contradictory findings and their possible causes, MIS Quarterly, Vol. 38 No. 1, pp. 305-326.

8. Chakravarty, A., Grewal, R., \& Sambamurthy, V. (2013), Information technology competencies, organizational agility, and firm performance: Enabling and facilitating roles. Information Systems Research, Vol. 4 No. 4), pp. 976-997.

9. Chen, C. - J., Huang, J. - W., \& Hsiao, Y. - C. (2010), Knowledge management and innovativeness: The role of organizational climate and structure, International Journal of Manpower, Vol. 31 No. 8, pp. 848-870.

10. Chen, C. - J., \& Huang, J. - W. (2009), Strategic human resource practices and innovation performance - The mediating role of knowledge management capacity, Journal of Business Research, Vol. 2 No. 1, pp. 104-114.

11. Crawford, J., Leonard, L. N. K. \& Jones, K. (2011), The human resource's influence in shaping IT competence, Industrial Management \& Data Systems, Vol. 111 No. 2, pp. 164-83.

12. Fornell, C., \& Larcker, D. F. (1981). Evaluating Structural Equation Models with Unobservable Variables and Measurement Error. Journal of Marketing Research, 18, 39-50.

13. Hair, J. F., Black, W. C., Babin, B. J., Anderson, R. E., \& Tatham, R. L. (2006), Multivariate data analysis (6th ed.), Uppersaddle River: Pearson Prentice Hall.

14. Khandekar, A., \& Sharma, A. (2005), Managing human resource capabilities for sustainable competitive advantage: An empirical analysis from Indian global organisations. Education + Training, Vol. 47 No. 8/9, pp. 628-639.

15. Kmieciak, R., Michna, A., \& Meczynska, A. (2012), Innovativeness, empowerment and IT capability: evidence from SMEs. Industrial Management \& Data Systems, Vol. 112 No. 5, pp. 707-728. 
16. Lengnick-Hall, M. L., \& Lengnick-Hall, C. A. (2012), Human Resource Management in the Knowledge Economy: New Challenges, New Roles, New Capabilities, Berrett-Koehler Publishers.

17. Lin, C., \& Hsu, M. - L. (2010), Holistic decision system for human resource capability identification. Industrial Management \& Data Systems, Vol. 110 No.2, pp. 230-248.

18. Mäkelä, K., Björkman, I., Ehrnrooth, M., Smale, A., \& Sumelius, J. (2013), Explaining stakeholder evaluations of HRM capabilities in MNC subsidiaries, Journal of International Business Studies, Vol. 44 No. 8), pp. 813-832.

19. Pérez-López, S. \& Alegre, J. (2012), Information technology competency, knowledge processes and firm performance. Industrial Management \& Data Systems, Vol. 112 No. 4, pp. 644-662.

20. Pérez-López, S., Montes Peon, J. M., \& Vazquez Ordas, C. J. (2005), Human Resource Practices, Organizational Learning and Business Performance, Human Resource Development International, Vol. 8 No. 2, pp. 147 - 164.

21. Podsakoff, P. M., MacKenzie, S. B., Lee, J. Y., \& Podsakoff, N. P. (2003), Common method biases in behavioral research: A critical review of the literature and recommended remedies, Journal of Applied Psychology, Vol.88 No.5, pp.879-903.

22. Song, M., Nason, R. W., \& Di Benedetto, C. A. (2008), Distinctive Marketing and Information Technology Capabilities and Strategic Types: A Cross-National Investigation, Journal of International Marketing, Vol. 16 No. 1, pp. 4-38.

23. Steijn, B., \& Van Den Muyzenberg, M. (2012). Human resource management in the information age. In I. Snellen, M. Thaens, \& W. Donk (Eds.), Public administration in the information age: Revisited (pp. 252-263). Amsterdam, The Netherlands: IOS Press.

24. Teece, D. J., Pisano, G. \& Shuen, A. (1997), Dynamic capabilities and strategic management, Strategic Management Journal, Vol. 18 No. 7, pp. 509-33.

25. Tippins, M. J. \& Sohi, R. S. (2003), IT competency and firm performance: Is organizational learning a missing link? Strategic Management Journal, Vol. 4 No. 8, pp. $745-761$.

\section{About the authors}

Lejla Turulja is a Senior Teaching Assistant at the School of Economics and Business Sarajevo, University of Sarajevo, B\&H. She received her PhD from the same University in 2016. She teaches and conducts research in Business Informatics, MIS, MIT, ICT and Digital economy. Her areas of research include IT, firms' capabilities, innovativeness, knowledge management, information management.

Author can be contacted at lejla.turulja@efsa.unsa.ba

Nijaz Bajgoric is a Professor of Business Computing and Information Technology Management at the School of Economics and Business, University of Sarajevo, B\&H. He has published papers in Intl. Journal of Business Continuity and Risk Management, Intl. Journal of Enterprise Information Systems, Kybernetes, Information Management and Computer Security, Information Systems Management, Industrial Management and Data Systems, Intl. Journal of Production Research, European Journal of Operational Research, Intl. Journal of Agile Management Systems, Journal of Concurrent Engineering. He published two books: "Continuous Computing Technologies for Enhancing Business Continuity" and "Always-On Enterprise Information Systems for Business Continuance: Technologies for Reliable and Scalable Operations", and authored/co-authored chapters in the edited books published by Wiley, Elsevier, Kluwer, Taylor\&Francis, IGI-Global, IOS Press, CRC Press, and Auerbach. Author can be contacted at nijaz.bajgoric@efsa.unsa.ba 